\title{
Analisis Penyampulan Data (DEA) Dua Peringkat dalam Mengenal Pasti Faktor Penentu Kecekapan Teknik Firma Pembuatan Pengangkutan
}

(Data Envelopment Analysis (DEA) Two Stages in Identify Determinant Factor of Efficiency Techniques for Transport in Manufacturing Firms)

\author{
MOHD FAHMY-ABDULLAH*, LAI WEI SIENG \& SULHI RIDZUAN
}

\begin{abstract}
ABSTRAK
Kertas ini bertujuan untuk mengukur skor kecekapan teknik dan mengenal pasti faktor penentu yang mempengaruhi kecekapan teknikal firma pembuatan pengangkutan menggunakan kaedah Analisis Penyampulan Data (DEA) dan data firma bagi tempoh 2005 hingga 2010. Peringkat pertama melibatkan pengiraan skor kecekapan melalui DEA dengan menggunakan data agregat. Pada peringkat kedua, skor kecekapan yang dihitung dalam peringkat pertama akan dijadikan sebagai pemboleh ubah bersandar untuk analisis regresi Tobit. Faktor penentu adalah nisbah modal-buruh, perbelanjaan latihan, nisbah taraf pendidikan, kadar upah, perbelanjaan teknologi maklumat dan komunikasi dan saiz firma. Keputusan menunjukkan purata skor kecekapan adalah tinggi bagi setiap subindustri. Kadar upah dan saiz firma merupakan penentu yang signifikan bagi faktor kecekapan firma pembuatan pengangkutan. Walau bagaimanapun, nisbah modal-buruh dan taraf pendidikan pada peringkat menengah didapati telah mengurangkan tahap kecekapan teknik. Implikasi daripada keputusan ini menunjukkan bahawa firma pembuatan pengangkutan perlu menitikberatkan saiz firma di samping meningkatkan pelaburan dalam modal manusia dan motivasi dalam kalangan pekerja seperti kenaikan kadar upah serta mengurangkan penggunaan modal yang sesuai dengan tahap teknologi dan pekerja mahir.
\end{abstract}

Kata kunci: Analisis Penyampulan Data; firma pembuatan pengangkutan; kecekapan teknik; regresi Tobit

\section{ABSTRACT}

The aim of this paper was to measure the level of technical efficiency and identify the determinants of this efficiency in the transport-manufacturing firms in Malaysia. The analysis involves two stages. The first stage is applying Data Envelopment Analysis (DEA) to calculate technical efficiency scores using agregate data for the period of 2005-2010 provided by the Department of Statistics, Malaysia. This score is then used as the dependent variable in the second stage to identify technical efficiency determinants using Tobit regression. In this model, the dependent variables are capital-labor ratio, expenditure on training, ratio of workers by educational level, wage rate, expenditure on information technology and communication (ICT) and firm size. The results showed that the levels of technical efficiencies are quite high for all subindustry. Wage and firm size have positive and significant on technical efficiency. The implication from these results is that the transport-manufacturing firms need to increase their investments in human capital, motivate workers and reduce capital usage to suit the level of technology and skilled workers.

Keywords: Data Envelopment Analysis; technical efficiency; transport-manufacturing firms; Tobit regression

\section{PENGENALAN}

Perkembangan firma pembuatan pengangkutan mengalami prestasi turun naik akibat liberalisasi perdagangan seperti kewujudan blok perdagangan Kawasan Perdagangan Bebas ASEAN (AFTA) dan penghapusan halangan perdagangan dalam kalangan negara ASEAN (MITI 2013). Skim Tarif Keutamaan Sama Rata (CEPT) dan aktiviti promosi pelbagai skim integrasi serantau yang dilaksanakan menambahkan lagi tekanan untuk meliberalisasikan industri ini di rantau ASEAN (Khalifah \& Talib 2008). Kesannya, sumbangan terhadap Keluaran Dalam Negara Kasar (KDNK) menurun pada tahun 2010 (2.4 peratus) berbanding 2005 (3.0 peratus) (Akaun
Negara Tahunan KDNK 2005-2011, 2012). Manakala kadar peningkatan jumlah import sebanyak RM21.7 bilion jauh lebih tinggi berbanding eksport yang hanya mencatatkan sebanyak RM5.3 bilion pada tahun 2010 dan mengalami pertumbuhan defisit dalam prestasi perdagangan. Nisbah modal-buruh pula mengalami penurunan daripada $119.5 \%$ pada tahun 2005 kepada $97.27 \%$ pada 2010. Jumlah pelaburan yang dilakukan juga adalah tidak konsisten apabila menunjukkan penurunan pada tahun 2009. Situasi ini menghasilkan purata pertumbuhan tahunan sebanyak -0.4\% (MITI 2013; NAP 2014). Secara keseluruhannya, prestasi semasa firma ini menunjukkan Malaysia hanya pada kedudukan ke-29 daripada 155 buah negara 
sedangkan industri ini merupakan salah satu industri yang dianggap sebagai pemacu transformasi negara dan dapat meningkatkan momentum pertumbuhan ekonomi negara seperti yang terkandung dalam Bidang Keberhasilan Utama Nasional (NKRA).

Situasi ini memperlihatkan tahap kecekapan industri ini haruslah tinggi bagi menangani kemunculan operasi baru, perubahan kecekapan teknik dan teknologi baru kesan daripada keterbukaan ekonomi dan liberalisasi perdagangan (Adhikary 2011; Kim et al. 2007). Walau bagaimanapun, penyelidikan lepas mendapati kajian mengenai kecekapan firma pembuatan pengangkutan di Malaysia masih kurang mendapat perhatian daripada penyelidik berbanding dengan industri lain. Kebanyakan kajian seperti Alias et al. (2008) dan Jajri dan Ismail (2014) hanya membincangkan firma pembuatan pengangkutan secara umum dalam kajian yang dijalankan. Di samping itu, penelitian terhadap faktor penentu juga tidak diambil kira untuk mendapatkan faktor penentu kecekapan seperti kajian Mahadevan (2002), Said dan Said (2004) dan Sulaiman (2012). Meskipun terdapat kajian lepas mengenai firma pembuatan pengangkutan termasuklah Amdun (2007), Ismail dan Jajri (2008) dan Rosli dan Kari (2008), namun kajian tersebut tidak mengkaji faktorfaktor penentu kecekapan.

Justeru, berdasarkan permasalahan dan kelompongan kajian ini, maka objektif kajian ini adalah mengenal pasti faktor penentu kecekapan firma pembuatan pengangkutan di Malaysia. Pendekatan Analisis Pengumpulan Data (DEA) dua peringkat merupakan pendekatan yang sesuai untuk menganalisis kajian ini. Peringkat pertama melibatkan pengukuran skor kecekapan firma pembuatan pengangkutan menggunakan data pada peringkat industri. Peringkat kedua pula, analisis Tobit dijalankan dengan skor kecekapan yang diperoleh daripada peringkat pertama dijadikan sebagai pemboleh ubah bersandar, manakala faktor penentu pula di anggap sebagai pemboleh ubah bebas. Pemboleh ubah bebas dipilih berdasarkan kepada kesesuaian kajian, kajian lepas dan sumber data sedia ada yang diperoleh daripada Jabatan Perangkaan Malaysia (DOS).

Kajian ini memberikan sumbangan besar terhadap kajian kecekapan yang terdahulu. Pertama, mengenal pasti faktor penentu yang dapat meningkatkan kecekapan dalam firma pembuatan pengangkutan di Malaysia. Ini berbeza dengan kajian terdahulu yang tidak mengambil kira faktor-faktor penentu kecekapan di dalam industri berkenaan. Kedua, industri ini masih kurang mendapat perhatian daripada penyelidik berbanding industri yang lain yang memberikan kelebihan kajian ini untuk melihat sejauh mana tahap dan faktor-faktor penentu kecekapan.

Struktur kajian ini terbahagi kepada beberapa bahagian; bahagian kedua membincangkan mengenai kajian kepustakaan. Sementara bahagian ketiga pula membincangkan mengenai metod kajian dan data. Bahagian seterusnya membincangkan mengenai keputusan kajian dan kesimpulan yang merupakan bahagian yang terakhir di dalam kajian ini.

\section{METOD DAN DATA}

\section{ANALISIS PENYAMPULAN DATA (DEA)}

Kaedah DEA yang diasaskan oleh Farrell (1957) merupakan satu teknik pengaturcaraan linear bukan parametrik yang bertujuan menilai prestasi kecekapan firma atau organisasi (bermaksud sebagai Unit Pembuat Keputusan atau DMU di dalam kepustakaan DEA). Charnes et al. (1978) dan Coelli (1996) telah menjalankan kajian lanjutan untuk mengukur tahap kecekapan dan mencadangkan satu model yang berorentasikan input iaitu Model Charnes, Cooper dan Rhodes (Model CCR). Model ini mengandaikan pengurangan input atau peningkatan output adalah pada kadar yang tetap (pulangan malar mengikut skala - CRS) bagi setiap DMU atau juga dikenali sebagai model CCRCRS yang memberikan skor kecekapan teknik General Technical Efficiency (GTE) (Nunamaker 1985).

Model CCR dengan andaian CRS boleh dirumuskan seperti berikut;

$$
\min l_{\mathrm{o}}-\varepsilon\left(\sum_{i=1}^{m} S_{i}^{-}+\sum_{r=1}^{s} S_{r}^{+}\right)
$$

tertakluk kepada:

$$
\begin{aligned}
& \sum_{i=1}^{N} \lambda_{f} x_{i f}=l_{0} x_{i f o}-S_{i}^{-} \quad \text { dengan } i=1 \ldots m \\
& \sum_{i=1}^{N} \lambda_{f} y_{r f}=S_{r}^{+}-y_{r f o} \quad \text { dengan } r=1 \ldots S \\
& \lambda_{f} \geq 0, f=1 \ldots N, S_{i}^{-}, S_{r}^{+} \geq 0 \forall i \text { dan } r
\end{aligned}
$$

dengan $x_{i f}$ dan $y_{r f}$ merupakan tahap input $i$ dan output $r$ yang digunakan oleh firma (atau DMU) $f$, Manakala $\mathrm{N}$ adalah jumlah firma; $\varepsilon$ adalah sebarang nombor positif (bukan Archimedes) yang sangat kecil untuk digunakan sebagai batas bawah kepada input dan output; $S_{i}^{-}$merupakan sisihan input manakala $S_{r}^{+}$ialah sisihan output dalam model pengoptimuman kecekapan peringkat pertama dan membolehkan pengiraan bagi perbezaan antara sasaran anggaran kecekapan firma yang tidak cekap dan nilai sebenar inputnya; $l_{\mathrm{o}}$ adalah skor kecekapan berorientasikan input dalam model pengoptimuman kecekapan peringkat pertama dan sekiranya sama dengan satu dan keduadua nilai slak adalah sama dengan sifar, maka firma, $f$ dikatakan sebagai cekap.

Model CCR mengandaikan bahawa tidak wujud hubungan yang signifikan antara saiz operasi dengan kecekapan dengan andaian bahawa skor kecekapan yang diperoleh adalah CRS. Andaian CRS pula hanya wajar apabila semua DMU beroperasi pada tahap yang optimum. Walau bagaimanapun, firma di dalam industri pembuatan pengangkutan berkemungkinan mengalami keadaan skala ekonomi (SE) yang menaik ataupun menurun (peningkatan jumlah output yang maksimum daripada penggunaan jumlah input yang minimum). Oleh itu, jika andaian CRS 
dilakukan dan pada masa yang sama tidak semua DMU beroperasi di tahap yang optimum, maka pengiraan skor kecekapan teknik akan tercemar dengan kecekapan skala.

Banker et al. (1984) telah menambah baik model CCR sebelum ini yang mengandaikan bahawa semua DMU adalah CRS. Model BCC (Banker et al. 1984) telah diperkenalkan untuk menilai skor kecekapan DMU yang mempunyai ciriciri andaian pengurangan input atau peningkatan output adalah pada kadar yang tidak tetap (Pulangan Berubah mengikut Skala-VRS). Model BCC-VRS memberikan skor kecekapan Local Pure Technical Efficiency (LPTE) (Nunamaker 1985). VRS mengukur skor kecekapan teknik tanpa mengesan SE. Jika terdapat perbezaan antara skor kecekapan teknik dengan LPTE daripada DMU yang tertentu, maka ia menunjukkan wujud ketidakcekapan skala, iaitu Kecekapan Teknik = PTE x SE. Keadaan ini menunjukkan bahawa keupayaan menggunakan sumbersumber firma yang diberikan, manakala kedua merujuk kepada mengeksploitasi ekonomi skala yang beroperasi pada titik sempadan pengeluaran yang menunjukkan CRS.

Model BCC yang berorentasikan input dengan andaian VRS dan dirumuskan sebagai masalah pemprograman linear boleh ditulis sebagai;

$$
\min l_{\mathrm{o}}^{*}-\varepsilon\left(\sum_{f=1}^{m} S_{i}^{-*}+\sum_{r=1}^{s} S_{i}^{+^{*}}\right)
$$

tertakluk kepada:

$$
\begin{aligned}
& \sum_{f=1}^{N} \lambda_{f} x_{i f}=l_{0} x_{i f o}-S_{i}^{-^{*}} \quad \text { dengan } i=1 \ldots m \\
& \sum_{f=1}^{N} \lambda_{f} y_{r f}=S_{r}^{+^{*}}-y_{r f o} \quad \text { dengan } r=1 \ldots S \\
& \sum_{f=1}^{N} \lambda_{f}=1 \\
& \lambda_{f} \geq 0, f=1 \ldots N, S_{i}^{-*}, S_{r}^{+^{*}} \geq 0 \forall i \text { dan } r
\end{aligned}
$$

dengan $S_{i}^{-*}$ dan $S_{r}^{+^{*}}$ merupakan slak bagi input dan output dalam model pengoptimuman kecekapan peringkat kedua; $l_{\text {* }}$ adalah skor kecekapan berorientasikan input dalam model pengoptimuman kecekapan peringkat kedua. Model DEA berorientasikan input dalam model (1) merupakan pengoptimuman kecekapan pada peringkat pertama dengan mengira $l_{\mathrm{o}}$ tanpa mengambil kira sebarang slak. Model (2) pula adalah pengoptimuman kecekapan pada peringkat kedua dengan mengoptimumkan slak melalui penambahbaikan $l_{\mathrm{o}}^{*}$.

Model BCC-VRS adalah berbeza dengan model CCR-CRS apabila skor kecekapan LPTE yang diperoleh menunjukkan faktor yang menyumbang kepada kecekapan sesuatu DMU adalah saiz operasi yang tidak tetap dan berlaku ketidakcekapan disebabkan oleh kekangan di dalam DMU. Ketidakcekapan tersebut menyebabkan, misalnya, firma tidak dapat beroperasi pada skala yang optimum. Kekangan tersebut diwakili oleh $\sum_{f=1}^{N} \lambda_{f}=1$ sebagai kekangan tambahan di dalam model BCC-VRS dengan andaian 'gabungan kecembungan bagi DMU tumpuan kajian membentuk PPS dan skor BCC-VRS dinamakan LPTE' (Cooper et al. 2007: 152) dengan kadar pertambahan input dan output yang tidak sama.

Jika kekangan kecembungan digugurkan di dalam model (2), maka model (1) digunakan untuk mendapatkan nilai TE dengan andaian CRS. Ini menunjukkan bahawa LPTE daripada DMU adalah sentiasa lebih besar atau sama dengan nilai TE. Berdasarkan andaian VRS pula, SE yang dihasilkan dapat diukur kerana kebanyakan firma yang beroperasi tidak mencapai tahap yang optimum. Ini berkemungkinan disebabkan oleh firma yang terlibat mempunyai saiz operasi yang terlalu kecil dan menyebabkan berlaku kejatuhan dalam pulangan menaik mengikut skala (IRS) ataupun firma yang terlibat mempunyai saiz operasi yang terlalu besar dan beroperasi dalam skala pulangan menurun (DRS) di dalam fungsi pengeluaran. Maka, firmafirma tersebut boleh memperbaiki kecekapan dengan menukar skala operasi firma tersebut. DEA Dinamik yang diperkenalkan oleh Fare dan Grosskopf(1996) merupakan kaedah yang sesuai untuk menilai prestasi sekumpulan DMU dalam sesuatu tempoh masa. Walau bagaimanapun, kaedah ini tidak dapat diaplikasikan dalam kajian ini kerana kaedah ini memerlukan data panel yang seimbang. Justeru, kajian ini menggunakan perisian DEAP yang dibangunkan oleh Coelli (1996) untuk mengira kecekapan subindustri.

\section{ANALISIS REGRESI TOBIT}

Coelli et al. (1998) telah mencadangkan pemboleh ubah persekitaran boleh dimasukkan dalam analisis DEA. Kebiasaannya, istilah 'pemboleh ubah persekitaran' merujuk kepada faktor yang boleh mempengaruhi kecekapan dalam sesebuah firma sebaliknya faktor tersebut adalah di luar kawalan pengeluar. Berdasarkan (2), skor DEA adalah antara selang 0 dan $1(0 \leq \& \leq 1)$ yang akan menjadikan pemboleh ubah bersandar tersebut menjadi pemboleh ubah bersandar yang terhad. Model Tobit sangat dikenali dengan kelebihannya dalam mengawal karakter taburan ukuran ketidakcekapan. Skor kecekapan DEA yang diperoleh pada peringkat pertama akan digunakan sebagai pemboleh ubah bersandar pada peringkat kedua dan menganalisis semula ciri-ciri firma dan pemboleh ubah persekitaran yang lain.

Model Tobit adalah seperti berikut;

$$
\begin{aligned}
& y_{i}^{*}=\beta^{\prime} x_{i}+\varepsilon_{i} \\
& y_{i}=\left\{\begin{array}{r}
y_{i}^{*}, \text { jika } y_{i}^{*}>0 \\
0, \text { jika } y_{i}^{*}=0
\end{array}\right. \\
& \varepsilon_{i} \sim N\left(0, \sigma^{2}\right)
\end{aligned}
$$


dengan $x_{i}$ adalah vektor pembolehubah bebas; $\beta$ ialah vektor parameter yang akan dianggar; $y_{i}^{*}$ adalah pemboleh ubah pendam, dan $y_{i}$ adalah skor kecekapan DEA (fungsi anggaran kebolehjadian $(L)$ dimaksimumkan untuk menyelesaikan $\beta$ dan $\sigma$ berdasarkan pemerhatian firma daripada $y_{i}$ dan $x_{i}$ adalah $L=\prod_{y_{i=0}} 1-F \prod_{y_{i>0}}\left(1 /\left(2 \prod \sigma^{2}\right)^{1 / 2}\right)$ $e^{\left.-\left[1 / 2 \sigma^{2}\right)\right]\left(y^{i}-\beta x i\right)^{2}}$ dengan $F_{i}=\int_{-\infty}^{\beta x_{i} / \sigma}\left(1 / 2 \prod^{1 / 2}\right) e^{-t^{2} / 2}$. Hasil darab yang pertama adalah terhadap cerapan dengan firma adalah cekap $100 \%(y=0)$ dan hasil darab yang kedua adalah terhadap cerapan dengan firma adalah tidak cekap $(y>0)$. $F_{i}$ adalah fungsi taburan normal pada $x_{i}$ ).

\section{SPESIFIKASI INPUT, OUTPUT DAN DATA.}

Berdasarkan Mankiw et al. (1995), (model yang digunakan dalam teori pertumbuhan eksogen mengandungi persamaan fungsi pengeluaran dengan dua input menghasilkan satu output) bagi kajian DEA, dua input dipilih. Input tersebut adalah: Modal ( $x 1$ ), yang merupakan nilai belian dan akaun harta tetap bagi pembinaan dan penambahbaikan sepanjang tahun rujukan (diukur dalam Ringgit Malaysia); dan pekerja ( $x 2$ ), yang merupakan semua yang mendapat upah dan keuntungan sebagai majikan atau pekerja. Manakala satu output digunakan iaitu jualan ( $y 1)$, ia merujuk kepada penjualan produk yang dikeluarkan oleh firma tersebut (diukur dalam Ringgit Malaysia).

Kajian ini menggunakan data pada peringkat industri yang diperoleh daripada Jabatan Perangkaan Malaysia (DOS) bermula pada tahun 2005 hingga 2010. Kekangan dan kesukaran untuk mendapatkan data yang lengkap merupakan cabaran terbesar dalam kajian ini. Pemilihan data telah dikategorikan kepada 6 subindustri pada tahap 3 digit mengikut MSIC 2000 dan MSIC 2008 iaitu pembuatan kenderaan bermotor, pembuatan kereta penumpang dan pembuatan kenderaan komersial; pembuatan kerangka untuk kenderaan bermotor dan pembuatan treler dan semi treler; pembuatan alat ganti dan aksesori untuk kenderaan bermotor; pembinaan kapal dan bot, pembinaan kapal dan struktur terapung dan pembinaan bot persiaran dan sukan; pembinaan pesawat dan kapal angkasa dan jentera berkaitan; pembuatan kelengkapan pengangkutan yang aktiviti tidak terkelas di tempat lain (t.t.t.l), pembuatan motosikal dan pembuatan basikal dan kenderaan orang kurang upaya.

Pemilihan data yang dilakukan oleh pihak Dos dilakukan secara rawak melalui proses simulasi berperingkat termasuklah mengenal pasti firma besar, sederhana dan kecil, jumlah output yang dikeluarkan, jumlah pekerja dan modal yang digunakan dan proses saringan dilakukan sekali lagi dengan beberapa firma telah digugurkan kerana mempunyai kekurangan maklumat yang berkaitan seperti tidak lengkap (nilai output atau modal tidak dilengkapkan) dan bilangan pekerja sangat kecil yang tidak memenuhi maksud firma kecil dan sederhana (kurang daripada 5 orang pekerja) yang memberikan kesan terhadap analisis sampel. Akhirnya, 611 data firma daripada 6 subindustri (DMU) yang terlibat telah disusun bagi tempoh dari 2005 hingga 2010. 611 data firma diagregatkan mengikut subindustri untuk digunakan dalam analisis DEA.

Seterusnya, kesemua data firma tersebut digunakan dalam regresi Tobit $(n=611)$. Pemboleh ubah atau faktor penentu yang terlibat di dalam analisis Tobit adalah nisbah modal-buruh (K/L), perbelanjaan latihan pekerja (TRE), nisbah pekerja mempunyai kelulusan tinggi (ijazah atau ijazah lanjutan atau setaraf dengannya) (TIER/L), nisbah pekerja mempunyai kelulusan menengah (STPM atau diploma atau setaraf dengannya) (SED/L), kadar upah (W/L), perbelanjaan komunikasi dan teknologi maklumat (ICT) dan pepatung saiz firma (1 firma kecil sederhana; lain $=0$ ) (DFSME). Selain itu, pepatung tahun juga dimasukkan bagi melihat variasi merentas tahun dengan tahun 2005 sebagai tahun rujukan. Pemilihan faktor penentu tersebut adalah berdasarkan kepada kajian lepas yang menggunakan faktor penentu yang sama di samping berpandukan kepada objektif dan maklumat data sedia ada. Manakala pemboleh ubah atau faktor luaran yang tidak diperlukan dikeluarkan untuk mengelakkan hasil kajian terjejas. Kesemua input, output dan faktor penentu telah mengambil kira tahun 2005 sebagai tahun asas dan semua pemboleh ubah telah diperbetulkan sebelum melakukan anggaran. Dapatlah dikatakan bahawa kajian pengukuran kecekapan dan faktor penentu ini adalah sesuai dan menepati kajian lepas pengukuran kecekapan bagi firma pembuatan pengangkutan.

JADUAL 1. Ringkasan subindustri dalam analisis DEA

\begin{tabular}{lc}
\hline Sub-industri & DMU \\
\hline $\begin{array}{l}\text { Pembuatan kenderaan bermotor, pembuatan kereta penumpang dan pembuatan kenderaan } \\
\text { komersial }\end{array}$ & 1 \\
Pembuatan kerangka untuk kenderaan bermotor dan pembuatan treler dan semi treler & 2 \\
Pembuatan alat ganti dan aksesori untuk kenderaan bermotor & 3 \\
$\begin{array}{l}\text { Pembinaan kapal dan bot, pembinaan kapal dan struktur terapung dan pembinaan bot } \\
\text { persiaran dan sukan }\end{array}$ & 4 \\
$\begin{array}{l}\text { Pembinaan pesawat dan kapal angkasa dan jentera berkaitan } \\
\text { Pembuatan kelengkapan pengangkutan yang aktiviti tidak terkelas di tempat lain (t.t.t.l), } \\
\text { pembuatan motosikal dan pembuatan basikal dan kenderaan orang kurang upaya }\end{array}$ & 5 \\
\hline
\end{tabular}




\section{KePUTUSAN DAN PERBINCANGAN}

\section{KEPUTUSAN DEA}

Secara umumnya, skor kecekapan firma pembuatan pengangkutan dapat dicapai berdasarkan subindustri yang berbeza dalam tempoh 2005 hingga 2010 (Jadual 2). Berdasarkan Jadual 2, untuk model CCR-CRS hanya subindustri 1 sahaja yang cekap dalam tempoh 2005 hingga 2010. Manakala model BCC-VRS pula, subindustri 1, 2 dan 5 merupakan subindustri yang cekap dalam tempoh 2005 hingga 2010. Sebaliknya, terdapat 5 subindustri daripada model CCR-CRS yang tidak cekap sepanjang tempoh 2005 hingga 2010 berbanding 3 subindustri yang tidak cekap daripada model BCC-VRS.

JADUAL 2. Keputusan DEA

\begin{tabular}{cc}
\hline \multicolumn{3}{c}{ Model CCR-CRS } \\
\hline DMU & Kecekapan \\
\hline 1 & 1.000 \\
2 & 0.567 \\
3 & 0.551 \\
4 & 0.594 \\
5 & 0.719 \\
6 & 0.648 \\
\hline & Model BCC-VRS \\
\hline DMU & \\
\hline 1 & Kecekapan \\
2 & 1.000 \\
3 & 1.000 \\
4 & 0.610 \\
5 & 0.644 \\
6 & 1.000 \\
\hline
\end{tabular}

Keputusan juga mengesahkan bahawa secara purata, skor kecekapan bagi model BCC-VRS adalah lebih tinggi iaitu sebanyak 0.843 berbanding model CCR-CRS iaitu sebanyak 0.680. Keputusan ini memberikan gambaran jelas bahawa pengurangan input atau peningkatan output bagi model BCC-VRS adalah pada kadar yang tidak tetap dan memberikan nilai kecekapan LPTE tanpa mengesan SE yang seterusnya memperoleh keputusan lebih baik berbanding model CCR-CRS yang mengandaikan pengurangan input atau peningkatan output adalah pada kadar yang tetap seperti yang ditegaskan oleh Banker et al. (1984). Di samping itu, model CCR-CRS juga mempunyai bilangan subindustri yang tidak cekap lebih banyak berbanding dengan model BCC-VRS. Berdasarkan keputusan tersebut, kajian ini telah memilih model BCC-VRS bagi tujuan mengenal pasti faktor penentu kecekapan. Berdasarkan model BCC-VRS, subindustri 1, 2 dan 5 merupakan subindustri yang cekap sepanjang tempoh 2005 hingga 2010 (bersamaan dengan nilai indeks 1.000).

\section{KEPUTUSAN REGRESI TOBIT}

Keputusan regresi Tobit dilaporkan dalam Jadual 3 menunjukkan bahawa faktor penentu kadar upah mempunyai hubungan yang signifikan pada aras keertian $1 \%$ dan mempunyai kesan positif (peningkatan kadar upah meningkatkan kecekapan). Berdasarkan Laporan Akaun Negara Tahunan KDNK (2005-2011) bagi tempoh 2005 hingga 2010, berlaku peningkatan sebanyak $67.0 \%$ atau RM1.2 bilion terhadap jumlah pembayaran gaji dan upah kepada pekerja firma pembuatan pengangkutan di Malaysia. Malah, jika dilihat jumlah purata kadar upah yang diterima oleh pekerja pada tempoh tersebut telah meningkat dari RM22.9 juta kepada RM26.6 juta. Ini menunjukkan firma cenderung untuk meningkatkan

JADUAL 3. Keputusan Regresi Tobit (pemboleh ubah bersandar = skor kecekapan)

\begin{tabular}{ccc}
\hline Pemboleh ubah tidak bersandar & Koefisien & Statistik t \\
\hline K/L & -0.571 & $-3.50^{* * *}$ \\
TRE & 0.000877 & 0.10 \\
TIER/L & 0.0113 & 0.04 \\
SED/L & -0.224 & $-2.06^{* *}$ \\
W/L & 0.131 & $2.82^{* * *}$ \\
ICT & 0.00173 & 0.12 \\
DSME & 0.0625 & $1.84^{*}$ \\
Pemalar & 0.295 & $2.11^{* * *}$ \\
\hline Pepatung tahun & & \\
\hline 2006 & -0.0569 & -1.20 \\
2007 & 0.0111 & 0.21 \\
2008 & 0.0514 & 0.98 \\
2009 & 0.0152 & 0.29 \\
2010 & 0.0112 & 0.24 \\
\hline
\end{tabular}

***signifikan pada $1 \%$;**signifikan pada $5 \%$; signifikan pada $10 \%$ 
jumlah upah bagi meningkatkan motivasi pekerja seterusnya meningkatkan kecekapan dan produktiviti firma. Keputusan ini juga menunjukkan kadar upah pekerja memainkan peranan yang penting seperti hasil kajian oleh Liew et al. (2012), Muhlau dan Lindenberg (2003) serta Yao dan Zhang (2001).

Begitu juga dengan faktor penentu saiz firma yang telah menyumbang kepada peningkatan kecekapan firma pembuatan pengangkutan. Ini terbukti apabila faktor saiz firma mempunyai hubungan yang signifikan pada aras keertian 10\% dan mempunyai kesan positif. Saiz firma sememangnya memainkan peranan yang penting untuk meningkatkan kecekapan di dalam firma pembuatan pengangkutan. Berdasarkan kajian Batra dan Tan (2003), tahap TE meningkat seiring dengan peningkatan saiz firma. Kajian lain seperti Amornkitvikai et al. (2014), Charoenrat et al. (2013) dan Sinani et al. (2008) juga membuktikan bahawa saiz firma dapat mempengaruhi tahap kecekapan firma.

Sebaliknya, keputusan kajian mendapati nisbah modal-buruh $(\mathrm{K} / \mathrm{L})$ adalah signifikan dan mempunyai kesan negatif terhadap kecekapan firma pembuatan pengangkutan (Jadual 3). Keadaan ini berkemungkinan disebabkan berlaku pertambahan modal seperti peningkatan teknologi dan pada masa sama kecekapan pekerja tidak ditingkatkan, oleh itu, ia memberi kesan kepada pekerja kerana terpaksa menyesuaikan diri dengan teknologi baru. Keputusan ini selari dengan Khalifah dan Talib (2008) yang mendakwa kapasiti berlebihan dalam penggunaan modal telah menyebabkan penurunan kecekapan dalam industri. Laporan Produktiviti 2005 dan 2010 mendapati firma pembuatan pengangkutan mengalami pertumbuhan tidak seimbang daripada $11.9 \%$ pada 2005 kepada $97.27 \%$ pada 2010 dan menyebabkan purata pertumbuhan tahunan negatif iaitu sebanyak $-4.0 \%$.

Begitu juga dengan faktor nisbah pekerja berkelulusan menengah yang didapati memberikan kesan negatif terhadap kecekapan firma pembuatan pengangkutan. Ini berkemungkinan disebabkan pekerja yang mempunyai pendidikan di peringkat menengah masih tidak mempunyai kepakaran dan kemahiran yang tinggi yang dapat menyumbang kecekapan kepada firma. Selain itu, tahun persekolahan merupakan salah satu peranan penting dalam mengenal pasti prestasi firma termasuklah output, keuntungan dan produktiviti (Ajibefun 2008; Idiong 2007; Murthy et al. 2009).

Sementara itu, faktor seperti perbelanjaan latihan kepada pekerja, nisbah pekerja berkelulusan tinggi dan perbelanjaan telekomunikasi, teknologi maklumat dan pepatung di dapati tidak mempunyai hubungan signifikan terhadap kecekapan firma pembuatan pengangkutan.

\section{KESIMPULAN}

Kajian ini mengesahkan bahawa model BCC-VRS telah dipilih kerana secara purata skor kecekapan model BCC-VRS adalah lebih tinggi berbanding dengan model CCR-CRS. Model BCC-VRS telah mengandaikan bahawa pengurangan input atau peningkatan output adalah pada kadar tidak tetap serta memberikan nilai kecekapan LPTE tanpa mengesan SE yang memberikan kesan terhadap keputusan skor kecekapan. Skor kecekapan yang diperoleh membuktikan bahawa hampir keseluruhan firma pembuatan pengangkutan mempunyai prestasi yang amat baik. Ini berkemungkinan disebabkan kebanyakan firma pembuatan pengangkutan telah melakukan banyak transformasi dan integrasi secara optimum ke dalam jaringan industri serantau dan antarabangsa yang memerlukan peningkatan eksport di pasaran dunia, menjaga kepentingan dengan menawarkan produk yang berkualiti tinggi dan selamat serta harga yang berpatutan dan akhirnya meningkatkan kecekapan dan produktiviti industri. Berdasarkan analisis regresi Tobit pula, kadar upah dan saiz firma menjadi petunjuk penting dalam meningkatkan kecekapan firma pembuatan pengangkutan. Bagi meningkatkan jumlah pengeluaran ataupun output pada tahap minimum serta meningkatkan kecekapan dan produktiviti, firma telah meningkatkan kadar upah dalam kalangan pekerja. Kadar upah yang lebih tinggi diterima oleh pekerja akan menggalakkan mereka untuk bekerja lebih keras dan menyumbang kepada kecekapan dan produktiviti lebih tinggi. Malah, Perlaksanaan Perintah Gaji Minimum (PGM) yang berkuatkuasa pada 1hb Julai 2016 merupakan satu langkah tepat untuk melindungi kepentingan pekerja selain tidak mengabaikan kepentingan majikan. Di samping itu, saiz firma juga amat penting dalam meningkatkan kecekapan dan produktiviti firma pembuatan pengangkutan. Walaupun terdapat kajian yang merumuskan bahawa tidak terdapat hubungan yang kukuh dan seragam antara saiz firma dengan tahap kecekapan, namun saiz firma yang mempunyai tahap penjenteraan yang lebih sofistikated mempunyai tahap kecekapan yang lebih tinggi.

Sebaliknya, nisbah modal-buruh dan taraf pendidikan peringkat menengah didapati telah memberikan kesan negatif kepada kecekapan firma pembuatan pengangkutan. Kajian ini mendapati walaupun firma pembuatan pengangkutan mempunyai modal yang cukup atau banyak serta para pekerja yang mempunyai taraf pendidikan menengah yang ramai, namun jika tahap kemahiran mereka tidak dipertingkatkan sudah pasti menjejaskan prestasi firma yang akhirnya mengurangkan tahap kecekapan secara keseluruhannya. Firma pembuatan pengangkutan sudah pasti memerlukan perubahan skala operasi kesan daripada permintaan tinggi dalam pasaran. Keadaan ini menuntut firma untuk menggunakan teknologi yang tinggi dalam industri. Walau bagaimanapun, kebergantungan kepada hanya teknologi tinggi tanpa meningkatkan kemahiran para pekerja sedia ada sudah pasti menjejaskan operasi firma. Oleh itu, firma seharusnya memberikan penekanan terhadap pelaburan di dalam modal insan kerana pekerja merupakan aset jangka masa panjang yang dapat memberikan pulangan positif sepanjang tempoh perkhidmatan pekerja dengan firma. Bagi melahirkan tenaga kerja yang terlatih dan berkemahiran, penekanan latihan perlulah diberikan 
kepada peningkatan kemahiran dan keupayaan seperti kepimpinan, pengurusan, kejuruteraan, kualiti, reka bentuk dan pengurusan kos meskipun pekerja tidak mempunyai taraf pendidikan yang tinggi. Kemahiran yang diperoleh melalui latihan yang diberikan dapat menyediakan tenaga kerja mahir sekaligus dapat mengurangkan kebergantungan kepada pekerja kurang mahir dan seterusnya membantu mewujudkan tenaga kerja mahir tempatan yang berpendapatan tinggi.

Di samping itu, penghasilan teknologi yang tinggi juga perlu seiring dengan tahap kecekapan dalam kalangan pekerja agar pekerja dapat menyesuaikan diri dengan teknologi yang baharu. Oleh itu, seharusnya penempatan pakar-pakar di dalam industri perlu dilakukan untuk meningkatkan momentum kemahiran kepimpinan, keupayaan pengurusan dan kualiti untuk pembangunan modal insan dalam kalangan pekerja.

\section{RUJUKAN}

Adhikary, B.K. 2011. FDI, trade openness, capital formation, and economic growth in Bangladesh: A linkage analysis. International Journal of Business and Management 6: 16.

Ajibefun, I.A. 2008. Technical efficiency analysis of microenterprises: Theoretical and methodological approach of the stochastic frontier production functions applied to Nigerian data. Journal of African Economies 17: 161-206.

Akaun Negara Tahunan (KDNK) 2005-2011. 2012. Putrajaya: Jabatan Perangkaan Malaysia.

Alias, R., Abu, M.L. \& Abdullah, A.M. 2008. Technical efficiency of small and medium enterprise in Malaysia: A stochastic frontier production model. International Journal of Economics and Management 2: 395-408.

Amdun, P.Z. 2007. Kajian mengenai perbezaan produktiviti antara syarikat asing dan syarikat tempatan dalam industri automotif di malaysia. Tesis 2007. Universiti Kebangsaan Malaysia (Tidak diterbitkan).

Amornkitvikai, Y., Harvie, C. \& Charoenrat, T. 2014. Estimating a technical inefficiency effects model for Thai manufacturing and exporting enterprises (SMEs): A Stochastic Frontier (SFA) and Data Envelopment Analysis (DEA) approach. In Proceedings of Informing Science \& IT Education Conference (InSITE).pp. 363-390.

Batra, G. \& Tan, H. 2003. SME Technical Efficiency and Its Correlates: Cross-National Evidence and Policy Implications. Washington, DC: World Bank.

Banker, R.D., Charnes, A. \& Cooper, W.W. 1984. Some models for estimating technical and scale inefficiencies in data envelopment analysis. Management Science 30: 1078-1092.

Charnes, A., Cooper, W.W. \& Rhodes, E. 1978. Measuring the efficiency of decision making units. European Journal of Operational Research 2(6): 429-444.

Charoenrat, T., Harvie, C. \& Amornkitvikai, Y. 2013. Thai manufacturing small and medium sized enterprise technical efficiency: Evidence from firm-level industrial census data. Journal of Asian Economics 27: 42-56.

Coelli, T.J. 1996. A Guide to FRONTIER version 4.1: A Computer Program for Stochastic Frontier Production and Cost Function Estimation (No. 7/96). New South Wales, Australia.

Coelli, T.J., Rao, D.S.P., O’Donnell, C.J. \& Battese, G.E. 1998. An Introduction to Efficiency and Productivity Analysis. Boston: Kluwer Academic Publisher.
Cooper, W.W., Seiford, L.M. \& Tone, K. 2007. The Basic CCR Model. In Data Envelopment Analysis A Comprehensive Test with Models, Applications, References and DEA-Solver Software. 2nd ed. New York: Springer Science Business Media, Inc.

Fare, R. \& Grosskopf, S. 1996. Intertemporal Production Frontier: With Dynamic DEA. Norwell: Kluwer.

Farrell, M.J. 1957. The measurement of productive efficiency. Journal of the Royal Statistical Society. Series A (General) 120(3): 253-290.

Idiong, I.C. 2007. Estimation of farm level technical efficiency in smallscale swamp rice production in cross river state of Nigeria: A stochastic frontier approach. World Journal of Agricultural Sciences 3(5): 653-658.

Ismail, R. \& Jajri, I. 2008. Analisis perubahan kecekapan teknikal, perubahan teknologi, pertumbuhan produktiviti faktor keseluruhan dan pertumbuhan output dalam industri peralatan pengangkutan di Malaysia. Sains Humanika 49: 31-48.

Jajri, I. \& Ismail, R. 2014. Total factor productivity and output growth of the services sector in Malaysia. Research Journal of Applied Sciences 9(12): 936-940.

Khalifah, N.A. \& Abdul Talib, B. 2008. Are foreign multinationals more efficient? A stochastic production frontier analysis of Malaysia's automobile industry. International Journal of Management Studies (IJMS) 15: 91-113.

Kim, S., Lim, H. \& Park, D. 2007. The effect of imports and exports on total factor productivity in Korea. Research Institute of Economy, Trade and Industry Discussion Paper Series (07-E).

Laporan Produktiviti 2005 dan 2010. Produktivitas Nasional Corporation, Petaling Jaya: Kuala Lumpur.

Liew, C.S.,Zulridah, M.N. \& Tee, B.A. 2012. Kesan ICT terhadap produktiviti pekerja dalam sektor perkhidmatan terpilih di Malaysia. Jurnal Ekonomi Malaysia 46(2): 115-126.

Mahadevan, R. 2002. Assessing the output and productivity growth of Malaysia's manufacturing sector. Journal of Asian Economics 12: 587-597.

MITI. 2013. National Automotive Policy 2013. Ministry of International Trade and Industry.

Muhlau, P. \& Lindenberg, S. 2003. Efficiency wages: Signals or incentives an empirical study of the relationship between wage and commitment. Journal of Management and Governance 7(4): 385-400.

Murthy, D.S., Sudha, M., Hegde, M.R. \& Dakshinamoorthy, V. 2009. Technical efficiency and its determinants in tomato production in Karnataka, India: Data Envelopment Analysis (DEA) Approach. Agricultural Economics Research Review 22(2): 215-224.

National Automotive Policy. 2014. Ministry of International Trade and Industry.

Nunamaker, T.R. 1985. Using data envelopment analysis to measure the efficiency of non-profit organizations: A critical evaluation. Managerial and Decision Economics 6(1): 50-58

Rosli, M. \& Kari, F. 2008. Malaysia's national automotive policy and the performance of proton's foreign and local vendors. Asia Pacific Business Review 14: 103-118.

Said, F. \& Said, S.M. 2004. Total factor productivity growth in Malaysian manufacturing sector: Emphasis on heavy industries. International Journal of Economics and Management 12: 2 .

Sinani, E., Jones, D.C. \& Mygind, N. 2008. Determinants of firmlevel technical efficiency: Evidence using stochastic frontier approach. Corporate Ownership \& Control 5: 225-239. 
Sulaiman, N. 2012. An input-output analysis of the total factor productivity growth of the Malaysian manufacturing sector, 1983-2005. Jurnal Ekonomi Malaysia 46: 147-155.

Yao, Y. \& Zhang, Q. 2001. Analysis of technical efficiency in Chinese industry. National Center for Economic Research, Tsinghua University, Working Paper 200103.

Mohd Fahmy-Abdullah*

Faculty of Technology Management and Business Universiti Tun Hussein Onn Malaysia

86400 Parit Raja, Batu Pahat, Johor Darul Takzim Malaysia
Lai Wei Sieng \& Sulhi Ridzuan

Faculty of Economics and Management

Universiti Kebangsaan Malaysia

43600 UKM Bangi, Selangor Darul Ehsan

Malaysia

*Pengarang untuk surat-menyurat; email: mohdfahmy@uthm. edu.my

Diserahkan: 14 Mac 2018

Diterima: 3 Februari 2019 